\title{
SEXUALITY EDUCATION AND TEACHER TRAINING IN PORTUGAL
}

\author{
Filomena Teixeira $^{1}$, Ana V. Rodrigues ${ }^{2}$, \& Diana Oliveira ${ }^{2}$ \\ ${ }^{I}$ Escola Superior de Educação de Coimbra e Centro de Investigação Didática e Tecnologia na Formação \\ de Formadores (Portugal) \\ ${ }^{2}$ Universidade de Aveiro e Centro de Investigação Didática e Tecnologia na Formação de Formadores
}

(Portugal)

\begin{abstract}
In 2017 we started a study on sexuality education (SE) involving two Public Higher Education Institutions (HEI) with master's degree courses for kindergarten and primary education teachers in Portugal. The objectives of the study are: i) to determine if the study plans of teacher training (both for kindergarten and primary education teachers) of the different HEI include curricular units of SE; ii) to verify whether the legal framework in Portugal includes issues directly related to SE; iii) to identify specific contents of SE as part of curricular guidelines in pre-school and primary education; iv) to identify what knowledge, attitudes and behaviours about sexuality exist among future kindergarten and primary education teachers; and v) to develop and evaluate curricular proposals through the design of didactic resources to support educational practices that promote an integrated approach to the different dimensions of SE. In this free paper presentation, the results related to the first three objectives of the study will be presented and discussed.

Although there is a legal framework in Portugal that integrates SE from the 1st to the 12th year of schooling, data analysis revealed that only a limited number of HEIs explicitly integrate curricular units directly associated with SE. In addition, the recent guidelines for curriculum support continue to give little or no relevance to the subject. Since kindergarten and primary education teacher training is the responsibility of HEIs, it is urgent to ask questions like these: 1. Are the teachers scientifically and pedagogically prepared to teach SE in schools? 2. How do HEIs plan to meet SE training needs? Is the political power conscious of the situation? Will there be a political will to think about SE strategies that involve schools, families and the community?
\end{abstract}

Keywords: Sexuality education, pre-service teacher training, legal framework.

\section{Introduction}

During the last decade, the visibility of sexuality has increased in the agenda of education and public health policies in several countries. International organizations such as the WHO, the UNESCO, the UNICEF and the UNAIDS promoted studies and published documents with proposals for a curricular approach along with guidelines for teacher and technician training in sexuality education (SE) in a perspective of human rights, gender and interculturality.

According to WHO (2000, p.6) "sexuality refers to a core dimension of being human which includes sex, gender, sexual and gender identity, sexual orientation, eroticism, emotional attachment/love, and reproduction. It is experienced or expressed in thoughts, fantasies, desires, beliefs, attitudes, values, activities, practices, roles, relationships. Sexuality is a result of the interplay of biological, psycho- logical, socio-economic, cultural, ethical and religious/spiritual factors. While sexuality can include all of these aspects, not all of these dimensions need to be experienced or expressed. However, in sum, our sexuality is experienced and expressed in all that we are, what we feel, think and do".

In Portugal, Carta de Aveiro ${ }^{1}$ calls for the promotion of sexual health, respect for gender equality, multiculturalism and diversity, highlighting the importance of a comprehensive, scientifically grounded and culturally relevant SE based on the respect for the Human Rights. Awareness of the challenges that human development poses at a global scale, invokes for greater accountability of the education systems to give curricular expression to the links between sexuality and gender inequality, poverty, violence, discrimination, health and civic rights.

${ }^{1}$ Carta de Aveiro on Sexuality and Sexual Education, approved at the $1{ }^{\text {st }}$ International Congress on Sexuality and Sexual Education, held in November 2010, at the University of Aveiro. In Teixeira et al [org.] (2010) pp. 413-416. 
Within the framework of their autonomy, the schools must be able to use the corridors of freedom for the construction of the curriculum, taking into account the dynamics of scientific and pedagogical knowledge, the challenges associated with different socio-cultural contexts and the ethical-political matrix of human rights. In this way, they enable young people to make informed, safe and responsible choices in the field of sexuality (Teixeira \& Marques, 2016).

\section{Design and objectives}

In 2017, we started a study on SE involving two Public HEIs with master's degree courses for kindergarten and primary education teachers ${ }^{2}$. The objectives of the study were: i) to determine if the study plans of teacher training (both for kindergarten and primary education teachers) of the different HEI include curricular units of SE; ii) to verify whether the legal framework in Portugal includes issues directly related to SE; iii) to identify specific contents of SE as part of curricular guidelines (eg programs, essential learning) in pre-school and primary education; iv) to identify what knowledge, attitudes and behaviors about sexuality exist among future kindergarten and primary education teachers; and v) to develop and evaluate curricular proposals through the design of didactic resources to support educational practices that promote an integrated approach to the different dimensions of SE. In this paper, only the results related to the first three objectives of the study will be presented and discussed.

\section{Methods}

The qualitative, interpretative and descriptive study was developed in three stages: the first involved research and analysis of study plans, programs, specific legislation on SE and other guiding documents; the second focused on the answers given by future educators and/or teachers of the 1st Cycle of Basic Education (CBE), to a questionnaire on knowledge, attitudes and behaviors and the third stage, still in progress, intends to elaborate, implement and evaluate didactic resources of support to integrative practices of SE.

In the first stage, 3 guiding questions were formulated: (1) Does the study plans of teacher training include curricular units of SE? (2) Does the legal framework in Portugal include issues directly related to SE? and (3) Is it possible to identify specific contents of SE as part of curricular guidelines?

To obtain answers for these questions we: (1) searched websites of Public Higher Education Institutions in Portugal offering undergraduate courses in Basic Education and/or Masters in Pre-School Education and Teaching of the 1st CBE, to collect, analyze and systematize curricula and programs of the curricular units related to SE; (2) investigated, analyzed and interpreted the current legislation in Portugal on SE; and (3) researched, analyzed and interpreted guidance documents at the level of organization and curricular management, for Pre-School Education and for the 1st CBE, to verify if they recommend SE.

\section{Discussion}

Based on the formulated questions, we herein present and discuss the obtained results:

\subsection{Does the study plans of teacher training include curricular units of SE?}

There are 20 public $\mathrm{HEIs}^{3}$ in Portugal that minister the degree in Basic Education - the only degree that allows access to professional master's degrees, namely the Master's Degree in Pre-School Education and Teaching $1^{\text {st }}$ Cycle of Basic Education. Of these 20 HEIs, $n=17$ teach the Master's Degree in Pre-School Education and Teaching $1^{\text {st }}$ Cycle of Basic Education (only HEIP7, HEIP8 and HEIP2 do not offer this course). In order to identify the importance attributed to SE in the training of kindergarten and primary education teachers, the websites of these HEIs were searched. This was carried out with the aim of knowing the curriculum of the two courses and identifying the presence of curricular units of SE. Subsequently, a second research was carried out in order to obtain the programs of other curricular units with the objective of analyzing them and identifying programmatic contents on SE.

Regarding Basic Education Courses, we noticed that four do not offer curricular units of SE and do not make the programs available online (HEIP3, HEIP9, HEIP12 and HEIP13). On the other hand, as

\footnotetext{
${ }^{2}$ This study was part of the research project "La educación en sexualidad y igualdad en la formación inicial de professorado y educadores sociales: análisis comparativo España, Portugal, Brasil y Argentina”, based in the University of Castilla La Mancha, having as partner institutions in Portugal, the School of Education of the Polytechnic Institute of Coimbra, the Department of Education and Psychology of the University of Aveiro and the Research Centre "Didactics and Technology in Education of Trainers".

${ }^{3}$ Of these, 13 HEIs are Polytechnic (HEIP) and the remaining 7 HEIs are University (HEIU). Based on this difference, the HEIPs were coded from 1 to 13 and the HEIU from 1 to 7.
} 
far as HEIP8 is concerned, the study plan provided on the website does not match the study plan published in Diário da República, so we were not able to access the program of these curricular units, particularly the one of the curricular unit "Health Education".

There are three HEIs that provide curricular units associated with Health or other areas where SE could be present, but we found that the curricular unit designation may be fallacious. In these three cases, the programs of each curricular unit were available and their analysis revealed that the contents do not provide SE (HEIP1: "Health Education" and "Earth and Life Sciences"; HEIU4: "Promotion and Education for Health"; HEIU7: "Health Promotion"). On the other hand, three other HEIs offer in their curricular plan curricular units associated with Health, but do not offer their program. Based on the previous cases, we cannot interpret the presence of curricular units associated with Health as a guarantee of the presence of SE (HEIP6: "Health Education", HEIU1: "Human Body and Health", HEIU5: "Health Education"). There is also 1 HEI (HEIP7) that despite having the program available, does not have any CU neither of SE nor related to Health.

There are two HEIs that present a different case, because although the curricular unit's programs are not available online, optional curricular units entitled "Sexuality, Health and Education" (HEIP4) and "Education for Gender Equality" (HEIP2) are offered in the Basic Education Course curriculum. While the first does not raise doubts about the presence of SE, the second does not allow us to infer whether SE is addressed or not.

Regarding the remaining six HEIs in which the curricular units' programs are made available, we found contents that focus on the health dimension associated with SE as well as Human Reproduction. References to gender identity and sexual attraction were also found. In HEIP11 there are two curricular units associated with SE: one that addresses the contents of the Reproductive System, morphology, physiology and diseases, alluding to fertilization, pregnancy and childbirth ("Life Sciences") and other where SE is explicitly part of the program ("Education for Health Promotion"). In HEIP5 there are also two curricular units - "Human Biology" and "Health Education". The first approaches human reproduction and the latter (optional curricular unit), approaches sexuality and sexually transmitted infections besides human reproduction. According to the programs, HEIU2 has two optional curricular units: "Human Biology" discusses the human body (anatomy, physiology and histology, reproduction, reproductive system, hormonal regulation) and "Health Education" includes topics such as gender identity and sexual education.

In HEIU3, the curricular unit "Integrated Nature Sciences II" includes an approach to the reproductive system and measures of health and disease prevention. Of note, in HEIP10, the curricular unit "Human Biology and Health" has a program where the reproductive system, sexually affective education (sexuality dimensions, interpersonal relations, feeling communication, stereotypes, grow and change, hygiene, sexual attraction, family planning, reproduction, pregnancy and birth, sexually transmitted infections), ill-treatment, neglect and sexual abuse of minors are explicitly covered. Finally, in HEIU6, the curricular unit "Human Biology and Health" is not restricted to human reproduction, as verified by the analysis of its program: male and female reproductive system; education for sexuality (family planning and contraceptive methods for men and women: prevention/protection of sexually transmitted infections; interpersonal relationships and sexuality; sexual education in schools).

From the analysis carried out, it was possible to verify that none of the Master's Degree in Pre-School Education and Teaching $1^{\text {st }}$ Cycle of Basic Education in any of the HEIs includes a formative offer of SE. Regarding Basic Education Courses, only one HEI clearly offers a curricular unit of SE, although optional. In the curricular units of Basic Education Courses where SE content is addressed, we noticed that six are not mandatory. As optional, the curricular units may or may not be taught and even when they are, may not be attended by all the students in the course.

\subsection{Does the legal framework in Portugal includes issues directly related to SE?}

In Portugal, the law 60/2009 establishes a regimen for the application of SE in schools, and provides for the compulsory design and implementation of SE projects, centered in the school, within the framework of Health Education, from the basic to secondary education. The Ordinance 196-A/2010, which regulates it, establishes the minimum contents to be addressed at each of the school levels. ${ }^{4}$

In order to answer the question, the two legal documents were analyzed, both at the level of the normative guidelines established (mainly in Law 60/2009), and of the contents to be addressed in the $1^{\text {st }}$ CBE (Ordinance 196-A/2010). The analysis revealed that there is no allusion to issues related to body, gender, sexual identities, sexual diversity, sexual practices, homophobia and family diversity.

In Ordinance 196-A / 2010, the following contents are established for the $1^{\text {st }} \mathrm{CBE}$ (from the 1st

${ }^{4}$ Republic Diary, Series I, Law 60/2009 of August 6 and Republic Diary, Series I, Ordinance 196-A/2010 of April 9. 
to the 4th year of schooling): "notion of body; the body in harmony with Nature and its social and cultural environment; notion of family; differences between boys and girls; protection of the body and the notion of limits, saying no to abusive approaches" (Ordinance 164-A - Annex Table). Regarding the 3rd and $4^{\text {th }}$ years of schooling, it states that "In addition to the items included in the physical environment programs, the teacher can develop topics that lead students to understand the need to protect their own bodies, to defend themselves against abusive approaches, advising that if are faced with doubts or problems of gender identity, they should feel the right to ask for help from people they trust in their families or at school "(ibid.).

A more detailed analysis of the aforementioned legislation reveals that the proposal of minimum contents of SE is based on the biomedical model of sexuality, has a weak thematic articulation and absence of an interdisciplinary view, moving away from the most current approaches on sexuality and gender, in particular by the absence of issues related to the media and the sexualization of the public space.

\subsection{Is it possible to identify specific contents of $\mathrm{SE}$ as part of curricular guidelines?}

Pursuing the third objective and seeking to answer this question, four guidance documents were analyzed in terms of organization and curricular management, for Pre-School Education and for the 1st CBE in Portugal, namely: i) Essential Learning - Basic Education (Direção Geral da Educação, 2018) ${ }^{5}$, ii) Profile of the Student Exiting Compulsory Schooling (Martins et al., 2017) ${ }^{6}$, iii) Curricular Guidelines for Pre-School Education (Silva, Marques, Mata, \& Rosa, 2016) ${ }^{7}$ and iv) Curricular Organization and Programs of Basic Education - 1st Cycle (Ministério da Educação, 2004) ${ }^{8}$.

Essential Learning - Basic Education (ELBE) corresponds to "a common set of knowledge to be acquired ... as well as the abilities and attitudes to be developed by all students" (Preamble of the Order no. 6944-A / 2018, of July 19). With regard to this document, we have analysed the subject Study of the Environment (present in the four years that comprise the 1st CBE) and the area of Citizenship and Development (primary and secondary education). The remaining three documents were analysed in their entirety. The Profile of the Student Exiting Compulsory Schooling (PSECS), is a reference document for the organization of the entire education system, contributing to the convergence and articulation of decisions on various dimensions of curriculum development. The Curricular Guidelines for Pre-School Education (CGPSE) are a reference document for the construction and management of the curriculum in pre-school education, considering the social evolution and the latest national and international studies. The document Curricular Organization and Programs of Basic Education - 1st Cycle (COPBE) has been revised since its publication in 1990, and is currently in force for some areas of the 1st CEB, namely the Study of the Environment.

In each of these documents were searched keywords related to the following categories: educate on equality; educate in tolerance / respect; educate in health / health; affective-sexual relations; body: bodily changes; sex / gender system; sexual identities; sexual abuse / violence; sexual diversity / sexual orientation; sexual practices; sexual phobias (homophobia, transphobia, ...); affectivity / pleasure / tenderness; sexuality / sex education; and family diversity. It should be noted that the following categories are totally omitted in all documents: affective-sexual relations; sexual abuse / violence; sexual practices; sexual phobias (homophobia, transphobia, ...). In all the documents analysed, it was found that more than half of the categories are not present.

In the opposite direction, the categories "Educate in health / health" and "System sex / gender" are the only ones that are present in all the documents. Three other categories emerge in three of the four guiding documents, namely: "Educate in tolerance / respect" category is present in all documents except COPBE; "Body: bodily changes" just does not figure in the PSECS; and category "Sexuality / sex education" is not present in the CGPSE. The categories "Educate in equality" and "Affectivity / Pleasure / Tenderness" are present only in two documents, respectively: ELBE and CGPSE; and the "Affectivity / Pleasure / Tenderness" category in CGPSE and COPBE. The remaining categories mark only one of the documents: "Family Diversity" in ELBE; "Sexual diversity / sexual orientation" in CGPSE; and "Sexual Identities" at COPBE.

\footnotetext{
${ }^{5}$ Approved by Order No. 6944-A / 2018, of July 19, published in Republic Diary No. 138/2018, Series II. They entered into force with Decree-Law no. 55/2018, of July 6, published in Republic Diary 129/2018, Series I.

${ }^{6}$ Approved by Order 6478/2017, July 26, published in Republic Diary 143/2017, Series II.

${ }^{7}$ Approved by Order 9180/2016 of July 19, published in Republic Diary 137, Series II.

${ }^{8}$ Published in 1990 (Order 139/ME/90, of August 16, published in Republic Diary 202, Series II), was revised (4th edition) with the entry into force of the guiding Organization and Management of Basic Education (Decree-Law 6/2001, of January 18, published in the Republic Diary 15/2001, Series IA, Statement of Rectification 4-A/2001, dated February 28, published in Republic Diary 50/2001, Series I-A, and Decree-Law 209/2002, of October 17, published in Republic Diary 240/2002, Series I-A).
} 
It should be noted that the CGPSE document, although recent, does not advocate Education in Sexuality since kindergarten. However, in comparison with the other documents analysed, it stands out for the use of inclusive language.

\section{Conclusions}

Since kindergarten and primary education teacher training is the responsibility of Higher Education Institutions (HEI), and given the results obtained in this first stage of the study and, it is urgent to ask new questions, namely: 1 . Are the teachers scientifically and pedagogically prepared to teach Sexuality Education (SE) in schools?; 2. How do HEIs plan to meet SE training needs? Is the political power conscious of the situation? Will there be a political will to think about SE strategies that involve schools, families and the community?

\section{Acknowledgments}

This work is financially supported by National Funds through FCT - Fundação para a Ciência e a Tecnologia, I.P., under the project UID/CED/00194/2019.

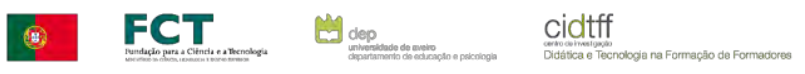

\section{References}

Direção-Geral da Educação. (2018). Aprendizagens Essenciais - Ensino Básico. Retrieved $10^{\text {th }}$ Sept, 2018, from http://www.dge.mec.pt/aprendizagens-essenciais-ensino-basico.

Martins, G. O., Gomes, C., Brocardo, J., Pedroso, J., Camilo, J., Silva, L., Encarnação, M., Horta, M., Calçada, M., Nery, R. \& Rodrigues, S. (2017). Perfil do aluno à saída da escolaridade obrigatória. Lisboa: Ministério da Educação, Direção-Geral da Educação.

Ministério da Educação. (2004). (4th Ed.). Organização Curricular e Programas do Ensino Básico - $1 .^{\circ}$ Ciclo. Lisboa: Departamento da Educação Básica.

PAHO; WHO \& WAS (2000). Promoción de la salud sexual. Recomendaciones para la acción. Proceedings. Guatemala: PAHO/OMS/WAS

Silva, I. (coord.), Marques, L., Mata, L. \& Rosa, M. (2016). Orientações Curriculares para a Educação Pré-Escolar. Lisboa: Ministério da Educação, Direção-Geral da Educação.

Teixeira, F. \& Marques, F.M. (2016). Sexualidad y género en la formación inicial de los e de las docentes. In Mateos Jiménez, A. y Manzanares Moya, A. (Dir.). Mejores Maestros, Mejores Educadores: Innovación y Propuestas en Educación. Cap.14.Málaga: Ediciones Aljibe.

Teixeira, F., Martins, I. P., Ribeiro, P. R. M., Chagas, I., Maia, A. C. B., Vilaça, T., Maia, A. F., Rossi, C. R., \& Melo, S. M. M. (Orgs.) (2010). Sexualidade e Educação Sexual: Políticas Educativas, Investigação e Práticas. Braga: Edições CIEd - Universidade do Minho (ebook). 